\title{
Terribacillus saccharophilus gen. nov., sp. nov. and Terribacillus halophilus sp. nov., spore-forming bacteria isolated from field soil in Japan
}

Correspondence
Sun-Young An
an12su@hotmail.com

\author{
Sun-Young An, ${ }^{1}$ Mika Asahara, ${ }^{2}$ Keiichi Goto, ${ }^{2}$ Hiroaki Kasai ${ }^{3}$ \\ and Akira Yokota ${ }^{1}$ \\ ${ }^{1}$ Institute of Molecular and Cellular Biosciences, The University of Tokyo, Yayoi, 1-1-1, \\ Bunkyo-Ku, Tokyo 113-0032, Japan \\ ${ }^{2}$ Microbiological and Analytical Group, Food Research Laboratories, Mitsui Norin Co. Ltd, \\ 223-1, Miyahara, Fujieda, Shizuoka 426-0133, Japan \\ ${ }^{3}$ Marine Biotechnology Institute Co. Ltd, 3-75-1, Heita, Kamaishi, Iwate 026-0001, Japan
}

\begin{abstract}
Three strains, $002-048^{\top}, \mathrm{RB} 589$ and $002-051^{\top}$, isolated from field soil in Japan, were characterized using a polyphasic approach. The isolates were Gram-positive, strictly aerobic, non-motile rods that formed ellipsoidal, subterminal endospores. The chemotaxonomic characteristics of these isolates included the presence of meso-diaminopimelic acid as the cell-wall peptidoglycan, anteiso- $\mathrm{C}_{15: 0}$ and anteiso- $\mathrm{C}_{17: 0}$ as the major cellular fatty acids and MK-7 as the predominant menaquinone. The DNA $\mathrm{G}+\mathrm{C}$ content was $44-46$ mol\%. Phylogenetic analyses based on $16 \mathrm{~S}$ rRNA gene sequences revealed that the isolates represented an independent lineage that is distinct from related taxa and exhibited less than $94.3 \%$ sequence similarity with respect to those taxa. Moreover, a DNA-DNA hybridization analysis showed that the three isolates represented two species. On the basis of their phenotypic and phylogenetic distinctiveness, the isolates represent two species within a novel genus, for which the names Terribacillus saccharophilus gen. nov., sp. nov. and Terribacillus halophilus sp. nov. are proposed. The type strain of $T$. saccharophilus is $002-048^{\top}\left(=\right.$ IAM $15309^{\top}=$ KCTC $\left.13936^{\top}\right)$ and the type strain of T. halophilus is $002-051^{\top}\left(=\operatorname{IAM} 15310^{\top}=\right.$ KCTC $\left.13937^{\top}\right)$.
\end{abstract}

The aerobic, spore-forming, Gram-positive, rod-shaped, moderately halophilic bacteria are a taxonomically diverse group whose members have been isolated from various environments. Phylogenetic and chemotaxonomic analyses have shown that halotolerant and moderately halophilic bacteria constitute several phylogenetically distinct lineages scattered throughout the genus Bacillus (Ash et al., 1991), described as the genera Halobacillus (Spring et al., 1996), Virgibacillus (Heyndrickx et al., 1998), Gracilibacillus (Wainø et al., 1999), Oceanobacillus (Lu et al., 2001), Lentibacillus (Yoon et al., 2002), Thalassobacillus (García et al., 2005) and Pontibacillus (Lim et al., 2005b). Three isolates with similar characteristics, $002-048^{\mathrm{T}}, \mathrm{RB} 589$ and $002-051^{\mathrm{T}}$, were isolated from field soil in Japan. On the basis of partial 16S rRNA gene sequence analyses, the strains were found to be closely related to members of the genera Oceanobacillus, Halobacillus, Thalassobacillus, Virgibacillus

The GenBank/EMBL/DDBJ accession numbers for the $16 \mathrm{~S}$ rRNA gene sequences of strains $002-048^{\top}$, RB589 and $002-051^{\top}$ are $\mathrm{AB} 243845, \mathrm{AB} 243847$ and $\mathrm{AB} 243849$, respectively.

The major fatty acids of strains $002-048^{\top}$, RB589 and $002-051^{\top}$ are listed in a supplementary table available in IJSEM Online. and Gracilibacillus. The aim of the present study was to elucidate the taxonomic position of the isolates, using polyphasic taxonomy (physiological and chemotaxonomic analyses, determination of the fatty acid composition, the quinone system and the $\mathrm{G}+\mathrm{C}$ content, and 16S rRNA gene sequence analysis). On the basis of these data, it is proposed that the three isolates represent two species within a novel genus, Terribacillus saccharophilus gen. nov., sp. nov. and Terribacillus halophilus sp. nov.

Strains $002-048^{\mathrm{T}}, \mathrm{RB} 589$ and $002-051^{\mathrm{T}}$ were obtained using the dilution plating technique on plate-count agar (Merck). Cell morphology and motility were examined by using phase-contrast microscopy (BX60 microscope; Olympus). Growth under anaerobic conditions was determined after 1 week incubation in an AnaeroPack (Mitsubishi Gas Chemical). Catalase activity was determined by means of bubble production from a $3 \% \mathrm{H}_{2} \mathrm{O}_{2}$ solution. Oxidase activity was determined by using cytochrome oxidase paper (Nissui Pharmaceutical). The API 20E and API 50CH microtest galleries (bioMérieux) were used to determine the physiological and biochemical characteristics. All suspension media were supplemented with $0.5 \times$ Herbst's artificial 
Table 1. Differential characteristics of the novel strains and members of phylogenetically related genera

Taxa: 1, strains $002-048^{\mathrm{T}}$, RB589 and $002-051^{\mathrm{T}} ; 2$, Oceanobacillus; 3, Virgibacillus; 4, Lentibacillus; 5, Halobacillus; 6, Thalassobacillus; 7, Pontibacillus; 8, Gracilibacillus. Data are from Lu et al. (2001), Lee et al. (2006), Heyndrickx et al. (1998), Yoon et al. (2002), Spring et al. (1996), García et al. (2005), Lim et al. (2005a, b) and Wainø et al. (1999). Symbols: +, positive; -, negative; v, varied according to strain; ND, not detected.

\begin{tabular}{|c|c|c|c|c|c|c|c|c|}
\hline Characteristic & 1 & 2 & 3 & 4 & 5 & 6 & 7 & 8 \\
\hline Spore shape ${ }^{\star}$ & $\mathrm{E}, \mathrm{S}$ & $\mathrm{E}$ & $\mathrm{E}, \mathrm{S}$ & $\mathrm{S}, \mathrm{O}$ & $\mathrm{E}, \mathrm{S}$ & $\mathrm{E}$ & S & $\mathrm{E}, \mathrm{S}$ \\
\hline Spore position $\dagger$ & ST, T & ST, T & ST, T & $\mathrm{T}$ & C, L, ST & $\mathrm{C}$ & $\mathrm{T}$ & $\mathrm{T}$ \\
\hline Motility & - & + & + & + & + & + & + & + \\
\hline Anaerobic growth & - & $\mathrm{V}$ & + & - & - & - & - & $\mathrm{V}$ \\
\hline $\begin{array}{l}\text { Maximum growth temperature } \\
\left({ }^{\circ} \mathrm{C}\right)\end{array}$ & 45 & 42 & 50 & $>40$ & $>40$ & 45 & 45 & 50 \\
\hline Requirement for $\mathrm{NaCl}$ & - & - & $\mathrm{V}$ & + & $\mathrm{V}$ & + & + & $\mathrm{V}$ \\
\hline $\begin{array}{l}\text { Maximum } \mathrm{NaCl} \text { concentration } \\
\text { for growth }(\%)\end{array}$ & 18 & 22 & $>10$ & $>20$ & $>20$ & 20 & 15 & $>15$ \\
\hline Oxidase activity & - & + & $\mathrm{V}$ & + & + & - & $\mathrm{V}$ & + \\
\hline Reduction of nitrate & - & - & $\mathrm{V}$ & + & - & + & $\mathrm{V}$ & + \\
\hline Voges-Proskauer test & + & - & - & ND & - & - & ND & - \\
\hline Diamino acid in murein $\neq$ & $m$-DAP & ND & $m$-DAP & $m$-DAP & Orn & $m$-DAP & $m$-DAP & $m$-DAP \\
\hline DNA G $+\mathrm{C}$ content $(\mathrm{mol} \%)$ & $44-46$ & $36-40$ & $37-38$ & 44 & $40-45$ & 42 & $41-42$ & $38-39$ \\
\hline Major fatty acid & $\begin{array}{l}\text { anteiso- } \\
\mathrm{C}_{15: 0} \\
\text { anteiso- } \\
\mathrm{C}_{17: 0}\end{array}$ & $\begin{array}{c}\text { anteiso- } \\
\mathrm{C}_{15: 0}\end{array}$ & $\begin{array}{l}\text { iso- } \mathrm{C}_{15: 0} \\
\text { anteiso- } \mathrm{C}_{15: 0}\end{array}$ & $\begin{array}{l}\text { anteiso- } \\
\mathrm{C}_{15: 0} \\
\text { iso- } \mathrm{C}_{16: 0}\end{array}$ & $\begin{array}{l}\text { anteiso- } \\
\mathrm{C}_{15: 0} \\
\text { iso- } \mathrm{C}_{16: 0}\end{array}$ & $\begin{array}{l}\text { anteiso- } \\
\mathrm{C}_{15: 0} \\
\text { iso- } \mathrm{C}_{16: 0} \\
\text { iso- } \mathrm{C}_{15: 0}\end{array}$ & $\begin{array}{c}\text { iso- } \mathrm{C}_{15: 0} \\
\text { anteiso- } \\
\mathrm{C}_{15: 0}\end{array}$ & $\begin{array}{c}\text { anteiso- } \\
\mathrm{C}_{15: 0}\end{array}$ \\
\hline
\end{tabular}

${ }^{\star}$ E, Ellipsoidal; S, spherical; O, oval.

$\uparrow$ C, Central; L, lateral; T, terminal; ST, subterminal.

$\ddagger m$-DAP, meso-diaminopimelic acid; Orn, ornithine.

seawater. Herbst's artificial seawater contains the following (per l distilled water): $\mathrm{NaCl}, 30 \mathrm{~g} ; \mathrm{KCl}, 0.7 \mathrm{~g} ; \mathrm{MgSO}_{4} .7 \mathrm{H}_{2} \mathrm{O}$, $5.3 \mathrm{~g} ; \mathrm{CaSO}_{4} \cdot 2 \mathrm{H}_{2} \mathrm{O}, 1.3 \mathrm{~g}$; and $\mathrm{MgCl}_{2} \cdot 6 \mathrm{H}_{2} \mathrm{O}, 10.8 \mathrm{~g}$. The API tests were read after $48 \mathrm{~h}$ incubation at $30^{\circ} \mathrm{C}$. The results of the morphological, biochemical and physiological analyses are shown in Tables 1 and 2.

The 16S rRNA gene sequences were determined using the 16S rRNA Gene Kit (Applied Biosystems) according to the protocols of the manufacturer. The 16S rRNA gene sequences of strains $002-048^{\mathrm{T}}, \mathrm{RB} 589$ and $002-051^{\mathrm{T}}$ were used for a BLAST search via the National Center for Biotechnology Information. The sequences obtained were aligned using the CLUSTAL W software package (Thompson et al., 1994), and evolutionary distances and $K_{\text {nuc }}$ values (Kimura, 1980) were generated. Alignment gaps and ambiguous bases were not taken into consideration when the 1387 bases of the 16S rRNA gene sequence were compared. The phylogenetic tree was constructed using the neighbour-joining method (Saitou \& Nei, 1987). The topology of the phylogenetic tree was evaluated by the bootstrap resampling method of Felsenstein (1985), with 1000 replicates. The similarity values were calculated using MEGA3 (Kumar et al., 2004). Almost-complete 16S rRNA gene sequences of strains $002-048^{\mathrm{T}}, \mathrm{RB} 589$ and $002-051^{\mathrm{T}}$ were subjected to comparative analysis. The $16 \mathrm{~S}$ rRNA gene sequence similarities for strain $002-048^{\mathrm{T}}$ with respect to
RB589 and $002-051^{\mathrm{T}}$ were 100 and $99.2 \%$, respectively. Strains $002-048^{\mathrm{T}}$ and $002-051^{\mathrm{T}}$ exhibited 16S rRNA gene sequence similarity values of 94.3 and $93.6 \%$, respectively,

Table 2. Differential characteristics of strain $002-048^{\top}$ and strain $002-051^{\top}$

Strains: $1,002-048^{\mathrm{T}} ; 2,002-051^{\mathrm{T}} .+$, Positive; - , negative.

\begin{tabular}{|lcc|}
\hline Characteristic & $\mathbf{1}$ & $\mathbf{2}$ \\
\hline Cell size $(\mu \mathrm{m})$ & $0.7-1.0 \times 2.3-4.8$ & $0.6-0.8 \times 2.8-4.8$ \\
Maximum NaCl concn & 16 & 19 \\
tolerated $(\%)$ & & \\
pH range & $6.0-10.0$ & $5.0-10.0$ \\
Acid produced from: & & - \\
Glucose & + & - \\
Sucrose & + & - \\
Assimilation of: & - & - \\
L-Arabinose & + & - \\
Galactose & + & - \\
Melibiose & + & 45.8 \\
Trehalose & + & \\
Raffinose & 44.0 & \\
DNA G+C content & & \\
(mol\%) & & \\
\hline
\end{tabular}


with respect to Oceanobacillus picturae, their closest phylogenetic relative, and the similarity values with respect to other taxa were less than $93.7 \%$. 16S rRNA gene sequence similarities of less than $95 \%$ between two bacteria indicate that they belong to different genera (Ludwig et al., 1998). Moreover, the phylogenetic analysis (Fig. 1) indicated that the three isolates formed a strong cluster, with $100 \%$ bootstrap support, representing a distinct lineage. The topologies of phylogenetic trees built using the maximumlikelihood and maximum-parsimony algorithms were similar to those of the tree constructed by neighbourjoining analysis (data not shown).

DNA-DNA hybridization was performed using the photobiotin-labelling method of Ezaki et al. (1989), with a multiwell plate reader (CytoFluor; PerSeptive Biosystems). The values for DNA-DNA hybridization between strain 002$048^{\mathrm{T}}$ and the other isolates were $99.9 \%$ (RB589) and $35.4 \%$ $\left(002-051^{\mathrm{T}}\right)$. Therefore, strains $002-048^{\mathrm{T}}$ and RB589 should be incorporated into a single species, and strain $002-051^{\mathrm{T}}$ should be considered as representing a separate species relative to strain $002-048^{\mathrm{T}}$ (Stackebrandt et al., 2002).

Genomic DNA was prepared according to the method of Marmur (1961), and the DNA G + C content was measured by HPLC according to the method described by Mesbah et al. (1989). The cellular fatty acids were identified with the Sherlock Microbial Identification System (MIDI). Bacterial strains were grown on marine agar 2216 (Difco) medium for 3 days at $25^{\circ} \mathrm{C}$. The analysis of the cell-wall peptidoglycan was carried out using the methods of Schleifer \& Kandler (1972). Respiratory quinone analyses were performed according to the method indicated by Collins \& Jones (1981). The chemotaxonomic characteristics determined were also congruent with the phylogenetic data. The DNA $\mathrm{G}+\mathrm{C}$ contents of $002-048^{\mathrm{T}}, \mathrm{RB} 589$ and $002-051^{\mathrm{T}}$ ranged from 44 to $46 \mathrm{~mol} \%$. Similar values were found in other low-G $+\mathrm{C}$, Gram-positive bacteria. The major fatty acids of the novel strains were anteiso- $\mathrm{C}_{15: 0}(47.6-63.5 \%)$ and anteiso- $\mathrm{C}_{17: 0}(17.9-34.8 \%$ ) (see Supplementary Table $\mathrm{S} 1$ in IJSEM Online). The two type strains, $002-048^{\mathrm{T}}$ and $002-$ $051^{\mathrm{T}}$, can be differentiated from each other by the amounts of anteiso- $\mathrm{C}_{15: 0}$ and anteiso- $\mathrm{C}_{17: 0}$ present (Supplementary Table S1 in IJSEM Online). The cell-wall peptidoglycan of strains $002-048^{\mathrm{T}}$ and $002-051^{\mathrm{T}}$ was based on mesodiaminopimelic acid, which corresponds with that of the phylogenetically closest neighbours (with the exception of members of the genus Halobacillus, which contain D-ornithine). The major isoprenoid quinone was MK-7, as for the other phylogenetically related genera.

The three isolates showed very low levels of 16S rRNA gene sequence similarity with respect to other taxa and formed a distinct lineage. Moreover, the isolates could be differentiated from their phylogenetically related neighbours on the basis of phenotypic characteristics (Table 1), such as motility, acetoin production, oxidase activity and nitrate reduction. The DNA G $+\mathrm{C}$ contents of the isolates were in the range $44-46 \mathrm{~mol} \%$, which is $4 \%$ lower than the values for members of the genera Virgibacillus (36-40 $\mathrm{mol} \%$ ), Lentibacillus (37-38 mol\%) and Gracilibacillus (38$39 \mathrm{~mol} \%$ ). The diamino acid in the murein of the isolates is meso-diaminopimelic acid (as opposed to ornithine for members of the genus Halobacillus). The cells of the isolates

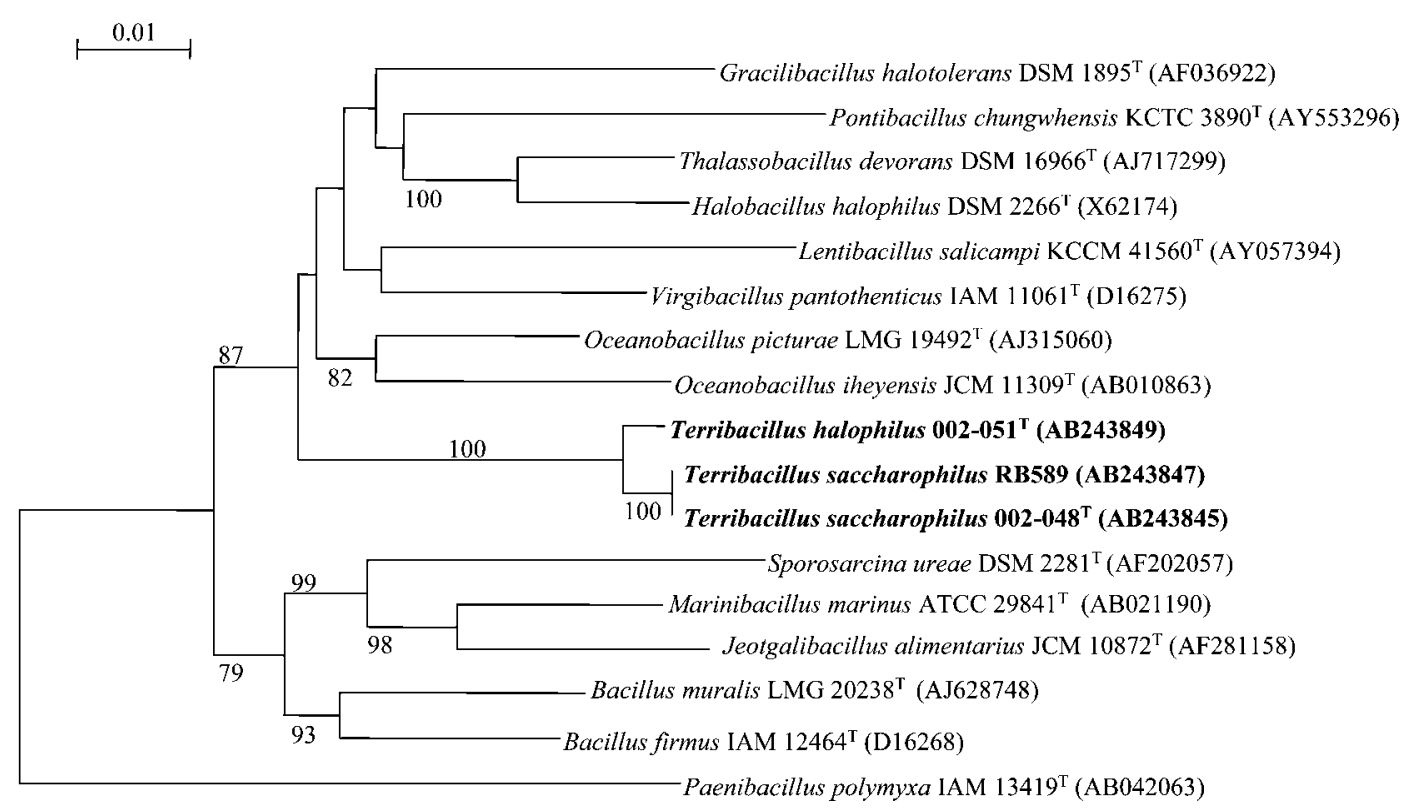

Fig. 1. Phylogenetic positions based on neighbour-joining of the 16S rRNA gene sequences of three isolates and other related taxa. Numbers at the nodes indicate the percentages of occurrence in 1000 bootstrapped trees; only those values greater than $70 \%$ are shown. Bar, 0.01 substitution per $100 \mathrm{nt}$. 
are non-motile, whereas most of the phylogenetically related genera (except Thalassobacillus) comprise members that are motile. The isolates reduce nitrates, but the members of the genus Thalassobacillus do not.

On the basis of the phylogenetic, physiological and chemotaxonomic data, therefore, strains $002-048^{\mathrm{T}}, \mathrm{RB} 589$ and $002-051^{\mathrm{T}}$ belong to two species within a novel genus, for which the names Terribacillus saccharophilus gen. nov., sp. nov. (strains $002-048^{\mathrm{T}}$ and RB589) and Terribacillus halophilus sp. nov. (strain $002-051^{\mathrm{T}}$ ) are proposed.

\section{Description of Terribacillus gen. nov.}

Terribacillus [Ter.ri.ba.cil'lus. L. n. terra earth; L. masc. n. bacillus a small staff; N.L. masc. n. Terribacillus earth (soil) bacillus (rod)].

Cells are non-motile, Gram-positive, aerobic rods. Ellipsoidal endospores are formed subterminally within swollen sporangia. Colonies are circular and convex. Catalasepositive. $\mathrm{H}_{2} \mathrm{~S}$ and indole are not produced. Nitrate is not reduced to nitrite. Gelatin is liquefied. Acetoin is produced. Urease and $\beta$-galactosidase are absent. The DNA G+C content is $44-46 \mathrm{~mol} \%$. The major cellular fatty acids are anteiso- $\mathrm{C}_{15: 0}$ and anteiso- $\mathrm{C}_{17: 0}$. MK-7 is the major component of the quinone system. The type species of the genus is Terribacillus saccharophilus.

\section{Description of Terribacillus saccharophilus sp. nov.}

Terribacillus saccharophilus (sac.cha.ro.phi'lus. Gr. n. sakkhar -aros sugar; Gr. adj. philos loving; N.L. masc. adj. saccharophilus sugar-loving).

The characteristics are the same as those given in the description of the genus, with the following additions. Cells are $0.7-1.0 \times 2.3-4.8 \mu \mathrm{m}$ in size. Colonies grown on trypticase soy agar containing $0.5 \times$ Herbst's artificial seawater are circular, convex and pale yellow. Temperature range for growth is $5-45^{\circ} \mathrm{C}$; $\mathrm{pH}$ range for growth is $6.0-10.0$. Growth occurs without $\mathrm{NaCl}$ and in the presence of $16 \%(\mathrm{w} / \mathrm{v})$ $\mathrm{NaCl}$. Optimum $\mathrm{NaCl}$ concentration for growth is $1-5 \%$ $(\mathrm{w} / \mathrm{v})$. Arginine dihydrolase, lysine decarboxylase, ornithine decarboxylase and tryptophan deaminase are absent. Citrate utilization is negative. Utilizes glycerol, galactose, glucose, fructose, mannose, rhamnose, mannitol, $\mathrm{N}$-acetylglucosamine, amygdalin, arbutin, aesculin, salicin, cellobiose, lactose, melibiose, sucrose, trehalose, raffinose, gentiobiose and D-tagatose, but does not utilize erythritol, D-arabinose, L-arabinose, ribose, D-xylose, L-xylose, adonitol, methyl $\beta$-D-xyloside, sorbose, dulcitol, inositol, sorbitol, methyl $\alpha$-D-mannoside, methyl $\alpha$-D-glucoside, maltose, inulin, melezitose, starch, glycogen, xylitol, D-turanose, D-lyxose, D-fucose, L-fucose, D-arabitol, L-arabitol, gluconate, 2-ketogluconate or 5-ketogluconate. Acid is produced from glucose, mannitol and sucrose, but not from inositol, sorbitol, rhamnose, melibiose, amygdalin or arabinose. The cell-wall peptidoglycan contains meso-diaminopimelic acid.
The predominant menaquinone system is MK-7. The major cellular fatty acids are anteiso- $\mathrm{C}_{15: 0}$ and anteiso- $\mathrm{C}_{17: 0}$. The DNA G + C content of the type strain is $44.0 \mathrm{~mol} \%$.

The type strain, $002-048^{\mathrm{T}}\left(=\mathrm{IAM} 15309^{\mathrm{T}}=\mathrm{KCTC} 13936^{\mathrm{T}}\right)$, was isolated from field soil from Tama City (Tokyo, Japan). The reference strain, RB589, was isolated from field soil in Saitama City (Japan).

\section{Description of Terribacillus halophilus sp. nov.}

Terribacillus halophilus (ha.lo.phi'lus. Gr. n. hals salt; Gr. adj. philos loving; N.L. masc. adj. halophilus salt-loving).

The characteristics are the same as those given in the description of the genus, with the following additions. Cells are $0.6-0.8 \times 2.8-4.8 \mu \mathrm{m}$ in size. Colonies grown on trypticase soy agar containing $0.5 \times$ Herbst's artificial seawater are circular, convex and pale yellow. Temperature range for growth is $5-45^{\circ} \mathrm{C} ; \mathrm{pH}$ range for growth is $5.0-10.0$. Growth occurs without $\mathrm{NaCl}$ and in the presence of $19 \%(\mathrm{w} / \mathrm{v})$ $\mathrm{NaCl}$. Optimum $\mathrm{NaCl}$ concentration for growth is $1-5 \%$ $(\mathrm{w} / \mathrm{v})$. Negative for arginine dihydrolase, lysine decarboxylase, ornithine decarboxylase, tryptophan deaminase and citrate utilization. Utilizes glycerol, L-arabinose, glucose, fructose, mannose, rhamnose, mannitol, $\mathrm{N}$-acetylglucosamine, amygdalin, arbutin, aesculin, salicin, cellobiose, lactose, sucrose, gentiobiose and D-tagatose but does not utilize erythritol, D-arabinose, ribose, D-xylose, L-xylose, adonitol, methyl $\beta$-D-xyloside, galactose, sorbose, dulcitol, inositol, sorbitol, methyl $\alpha$-D-mannoside, methyl $\alpha$-Dglucoside, maltose, melibiose, trehalose, inulin, melezitose, raffinose, starch, glycogen, xylitol, D-turanose, D-lyxose, D-fucose, L-fucose, D-arabitol, L-arabitol, gluconate, 2-ketogluconate or 5-ketogluconate. Acid is produced from mannitol, but not from glucose, inositol, sorbitol, rhamnose, sucrose, melibiose, amygdalin or arabinose. The cell-wall peptidoglycan contains meso-diaminopimelic acid. The major quinone system is MK-7. The major cellular fatty acids are anteiso- $\mathrm{C}_{15: 0}$ and anteiso- $\mathrm{C}_{17: 0}$. The DNA G+C content of the type strain is $45.8 \mathrm{~mol} \%$.

The type strain, 002-051 ${ }^{\mathrm{T}}\left(=\operatorname{IAM} 15310^{\mathrm{T}}=\mathrm{KCTC} 13937^{\mathrm{T}}\right)$, was isolated from field soil in Tama City (Tokyo, Japan).

\section{References}

Ash, C., Farrow, J. A. E., Wallbanks, S. \& Collins, M. D. (1991). Phylogenetic heterogeneity of the genus Bacillus revealed by comparative analysis of small-subunit-ribosomal RNA sequences. Lett Appl Microbiol 13, 202-206.

Collins, M. D. \& Jones, D. (1981). Distribution of isoprenoid quinone structural types in bacteria and their taxonomic implications. Microbiol Rev 45, 316-354.

Ezaki, T., Hashimoto, Y. \& Yabuuchi, E. (1989). Fluorometric deoxyribonucleic acid-deoxyribonucleic acid hybridization in microdilution wells as an alternative to membrane filter hybridization in which radioisotopes are used to determine genetic relatedness among bacterial strains. Int J Syst Bacteriol 39, 224-229. 
Felsenstein, J. (1985). Confidence limits on phylogenies: an approach using the bootstrap. Evolution 39, 783-791.

Garcia, M. T., Gallego, V., Ventosa, A. \& Mellado, E. (2005). Thalassobacillus devorans gen. nov., sp. nov., a moderately halophilic, phenol-degrading, Gram-positive bacterium. Int J Syst Evol Microbiol 55, 1789-1795.

Heyndrickx, M., Lebbe, L., Kersters, K., De Vos, P., Forsyth, C. \& Logan, N. A. (1998). Virgibacillus: a new genus to accommodate Bacillus pantothenticus (Proom and Knight 1950). Emended description of Virgibacillus pantothenticus. Int J Syst Bacteriol 48, 99-106.

Kimura, M. (1980). A simple method for estimating evolutionary rates of base substitutions through comparative studies of nucleotide sequences. J Mol Evol 16, 111-120.

Kumar, S., Tamura, K., Jakobsen, I. B. \& Nei, M. (2004). MEGA3: integrated software for molecular evolutionary genetics analysis and sequence alignment. Brief Bioinform 5, 150-163.

Lee, J. S., Lim, J. M., Lee, K. C., Lee, J. C., Park, Y. H. \& Kim, C. J. (2006). Virgibacillus koreensis sp. nov., a novel bacterium from a salt field, and transfer of Virgibacillus picturae comb. nov. with emended descriptions. Int J Syst Evol Microbiol 56, 251-257.

Lim, J. M., Jeon, C. O., Park, D. J., Kim, H. R., Yoon, B. J. \& Kim, C. J. (2005a). Pontibacillus marinus sp. nov., a moderately halophilic bacterium from a solar saltern, and emended description of the genus Pontibacillus. Int J Syst Evol Microbiol 55, 1027-1031.

Lim, J. M., Jeon, C. O., Song, S. M. \& Kim, C. J. (2005b). Pontibacillus chungwhensis gen. nov., sp. nov., a moderately halophilic Grampositive bacterium from a solar saltern in Korea. Int J Syst Evol Microbiol 55, 165-170.

Lu, J., Nogi, Y. \& Takami, H. (2001). Oceanobacillus iheyensis gen. nov., sp. nov., a deep-sea extremely halotolerant and alkaliphilic species isolated from a depth of $1050 \mathrm{~m}$ on the Iheya Ridge. FEMS Microbiol Lett 205, 291-297.

Ludwig, W., Strunk, O., Klugbauer, S., Klugbauer, N., Weizenegger, M., Neumaier, J., Bachleitner, M. \& Schleifer, K.-H. (1998). Bacterial phylogeny based on comparative sequence analysis. Electrophoresis 19, 554-568.

Marmur, J. (1961). A procedure for the isolation of deoxyribonucleic acid from micro-organisms. J Mol Biol 3, 208-218.

Mesbah, M., Premachandran, U. \& Whitman, W. B. (1989). Precise measurement of the $\mathrm{G}+\mathrm{C}$ content of deoxyribonucleic acid by highperformance liquid chromatography. Int J Syst Bacteriol 39, 159-167.

Saitou, N. \& Nei, M. (1987). The neighbor-joining method: a new method for reconstructing phylogenetic trees. Mol Biol Evol 4, 406-425.

Schleifer, K. H. \& Kandler, O. (1972). Peptidoglycan types of bacterial cell walls and their taxonomic implications. Bacteriol Rev 36, 407-477.

Spring, S., Ludwig, W., Marquez, M. C., Ventosa, A. \& Schleifer, K. H. (1996). Halobacillus gen. nov., with descriptions of Halobacillus litoralis sp. nov. and Halobacillus trueperi sp. nov., and transfer of Sporosarcina halophila to Halobacillus halophilus comb. nov. Int J Syst Bacteriol 46, 492-496.

Stackebrandt, E., Frederiksen, W., Garrity, G. M., Grimont, P. A. D., Kämpfer, P., Maiden, M. C. J., Nesme, X., Rossello-Mora, R., Swings, J. \& other authors (2002). Report of the ad hoc committee for the re-evaluation of the species definition in bacteriology. Int J Syst Evol Microbiol 52, 1043-1047.

Thompson, J. D., Higgins, D. G. \& Gibson, T. J. (1994). CLUSTAL W: improving the sensitivity of progressive multiple sequence alignment through sequence weighting, position specific gap penalties and weight matrix choice. Nucleic Acids Res 22, 4673-4680.

Wainø, M., Tindall, B. J., Schumann, P. \& Ingvorsen, K. (1999). Gracilibacillus gen. nov., with description of Gracilibacillus halotolerans gen. nov., sp. nov.; transfer of Bacillus dipsosauri to Gracilibacillus dipsosauri comb. nov., and Bacillus salexigens to the genus Salibacillus gen. nov., as Salibacillus salexigens comb. nov. Int J Syst Bacteriol 49, 821-831.

Yoon, J. H., Kang, K. H. \& Park, Y. H. (2002). Lentibacillus salicampi gen. nov., sp nov., a moderately halophilic bacterium isolated from a salt field in Korea. Int J Syst Evol Microbiol 52, 2043-2048. 